relation to the outbreaks, seeing that they had to rely upon newspaper reports for the times of the outbreaks.

\section{The Disturbing Influence of Science}

LECTURING to the Science Federation of the University of Manchester on January 23 under the title "The Irresponsibility of Science", Prof. H. Levy asserted that the problems of unemployment and the distribution of leisure are problems which the man of science must help to solve. It is part of the duty of the scientific man to examine the external properties of science and to face the ethical problems which the application of scientific discoveries is liable to create. The habit engendered in the scientific worker by his very method of endeavouring to isolate objects or causes and consider the influence of single factors in a problem has a very real danger in that it leads scientific workers to assume that all scientific questions are independent of ethics. Practically all scientific work, however, has a social aspect and its social properties cannot be clearly separated from its scientific properties any more than theoretical and applied science can be sharply demarcated. At the present time we are being forced to consider indeed the limit beyond which the process of improving the weapons of production is likely to disturb the structure of the original scientific movement itself. The scientific worker cannot ignore the fact that in practice what is intended as a gift of more leisure for all becomes unemployment and loss of consuming power for some. Scientific men must endeavour to find what factors go to the creation of an unstable society under the impact of science in this way. Prof. Levy suggested that scientific men should analyse the tendencies of science so that they could direct them. Science, which has been a revolutionary factor, has now become a disturbing factor in the world, affecting the stability of communities, and the study of that disturbance is one for international science.

\section{Science and the Textile Industry}

Speaking on January 26 on the textile industry in the course of lectures on industrial affairs which are being given to the students of the Imperial Coilege of Science and Technology, Dr. Kenneth Lee expressed his belief that the rapid development of scientific research will prove the best investment the textile industry can make. The British Cotton Industry Research Association has undoubtedly the best equipped textile research institute in the world, but although about eighty per cent of those engaged in production contributed to it, in relation to the magnitude of the industry the amount subscribed is negligible. Dr. Kenneth Lee believes that if the necessary financial support is forthcoming, we could dominate to a large extent the cotton textile field in the production of new inventions during the next few years. In addition to utilising science, the cotton industry must also employ men in its mills who can understand the work that science is doing. Dr. Kenneth Lee referred in particular to the way in which science, by introducing means of artificial humidification and ventilation, has not only discounted what was once supposed to be a great advantage of the Lancashire industry-its damp climate-but has made it possible to obtain uniform conditions throughout the year with higher output and more efficient use of automatic machinery.

\section{Direct-Current Generators for Electrostatic Precipitation}

IN the English Electric Co.'s Journal for October, a description is given of the high-pressure D.C. dynamos it constructs for use in electrostatic precipitation plant. The Whessoe Foundry and Engineering Co., Ltd., specialises in apparatus for fog and mist extraction, and the English Electric Co.'s dynamos are specially designed to work with its plant. The removal of suspended particles from large volumes of gas is an important commercial problem at the present time. Electrostatic precipitation is now regarded as the most efficient and economical method for cleaning gases. The English Electric Co. has designed many high-pressure D.c. machines for radio transmission purposes, and the new dynamos are based on the experience gained in radio work. The generating unit for a typical equipment has to supply a current of about $0 \cdot 15$ amperes at a pressure of 45 kilovolts. The unit consists of a driving motor made to suit the local supply, coupled to three generators connected in series. The frames of the machines are insulated from the earth by individual supports of solid porcelain. The whole of the high-pressure apparatus is enclosed by screens which separate it from the driving motor and prevent unauthorised access. A simple interlock on the door renders it impossible for anyone to enter the high-pressure compartment when the generators are running. As a further precaution, every conductor which is at high pressure when the machine is running is connected with the earth when the set is at 'standstill'. Accidental shocks are thus avoided. A notable feature of the set is its ability to withstand a short circuit without a 'flash-over'. A model precipitation equipment was shown in action at the English Electric Co.'s exhibition last November.

\section{Ship Researches at the William Froude Laboratory}

Durrng the last ten or twelve years, no fewer than twenty-two papers have been contributed to the transactions of the Institution of Naval Architects, the North-East Coast Institution of Engineers and Shipbuilders and other bodies, by the members of the staff of the William Froude Laboratory, National Physical Laboratory, Teddington. Among these papers are six on the effect of weather conditions on the propulsion of ships, seven on the manœuvring of ships and six on the efficiency of screw propellers. The other papers deal with the hulls of flying boats and ship propulsion data. Needless to say, all the papers are of permanent value and they have now been re-issued as vol. 23 of the Collected Researches of the National Physical Laboratory (London : H.M. Stationery Office. 20s. net). Arrangements have also been made to publish them in five groups. Each 
paper is preceded by a short abstract and the volume has an adequate index, but the reprint does not contain reports of the discussions, for which reference will have to be made to the transactions of the various societies. The majority of the papers, of course, deal with investigations carried out with models in the Alfred Yarrow Tank, but three of Mr. Kent's papers on the effect of weather conditions on the propulsion of ships contain his observations made on several voyages across the Atlantic in rough weather, when the routine of the laboratory was abandoned for all the discomforts of the sea.

\section{Recent Acquisitions at the Natural History Museum}

THE skin and skull of a hybrid between a lion and a leopard, which was bred in the Gardens of Kolhapur, has been presented to the Department of Zoology by Col. F. W. Wodehouse. This specimen, which had reached the age of three years, resulted from a union between a male leopard and a lioness, there being two cubs in the litter, the other one dying when about two and a half months old. These appear to be the only hybrids between a lion and leopard ever recorded. Among a small collection of mammals from Tanganyika Territory collected and presented by Mr. W. G. Cubitt-Currie is a new species of golden mole belonging to the genus Chlorotalpa. Purchases for the Department of Zoology include a specimen of the giant squid, Architeuthis, stranded in West Bay, Scarborough, on January 14. It is about 20 feet in length, including the tentacles. A notable addition to the Department of Geology is a complete specimen of the ancient shark, Hybodus Lauffianus. This is no less than seven feet long, and was discovered in the Upper Lias of Hobzmader, Württemberg. As with some specimens of Ichthyosaurus and other creatures found at this famous locality, not merely the skeleton, but also soft tissues, notably the skin, are present. The Department of Botany has received from the Godman Trustees a further collection of 848 specimens of flowering plants collected by Mr. R. G. N. Young in the Lunda province of Angola. The whole collection forms a valuable addition to our know. ledge of the flora of this part of Angola and is especially noteworthy on account of the wealth of material of aquatic species. Amongst the purchases are 540 specimens collected in Brazil by B. H. Krukoff and a further series of 268 type specimens of the liverwort family Jubulearum.

\section{Farmers' Guide to Agricultural Research}

The Royal Agricultural Society of England (16 Bedford Square, W.C.1) has issued the seventh of its series of annual summaries of scientific and economic research $(1 s .3 d$. post free). The volume deals mainly with work carried out in Great Britain but also includes the results of colonial and foreign investigations so far as they have a bearing on British agriculture. This year the publication has been issued under a new title, namely, "The Farmer's Guide to Agricultural Research in 1931" in place of "Agricultural Research", by which it has been known hitherto. The change has been made in order to emphasise the main object of the publication, which is to provide the farmer with the most up-todate information in all the leading branches of agriculture in a summarised and simple form. Apart from the title, the character of the volume remains unaltered, except that the section on crop and plant breeding is temporarily suspended and a new section on pests and parasites is included. The remaining sections, on dairy farming and dairy work, prevention and treatment of diseases of animals, farm economics, the feeding of live stock, farm implements and machinery, and soils and manures need only be cited to show how wide is the field of inquiry covered. Since each section is prepared by a recognised authority on the subject, the publication cannot fail to be of interest and practical value to the farmer, agricultural organiser and student.

\section{Trout Fishing in New Zealand}

AN interesting communication on the effects of intensive angling on the depreciation of trout-fishing in the Oreti (or New River) in New Zealand is given by Prof. E. Percival in Fisheries Bulletin No. 5 of the New Zealand Marine Department. The European trout when introduced into New Zealand showed remarkable fitness to their new environment by their great growth and in the early years afforded excellent opportunities for anglers. In recent years, however, there have been signs that the fishing is falling off to a considerable extent. This had been popularly attributed to a number of causes, such as the removal of the bush, leading to a decline in the food supply, the destruction of grasshoppers and cicadas by imported birds, or a change in the growth rate of the fish themselves. By examining old anglers' diaries, studying the food supply and growth of the trout, and using the statistics of angling societies, the author has shown that in all probability the decline in the fisheries is due to the great increase in the number of anglers themselves in recent years and to the opening up of fresh ragions made accessible by modern rapid means of transport. The apparent decrease in size attained by the fish is due to the killing off of the older fish and the rapid removal of the smaller fish before they have time to reach a large size. In this publication Prof. Percival gives some valuable information on the food relations in inland waters of New Zealand, following up the work he has already done on the fauna of the streams of Great Britain.

\section{Tests of Hearing}

A Commitree of the Section of Otology of the Royal Society of Medicine which was appointed in 1929 to consider tests of hearing has now issued its report (Longmans, Green and Co., Ltd., London. 2s. $6 d$.). Tests of hearing by tuning forks, which are widely used, were first considered. It was found, however, that there is no uniformity in the kinds or construction of forks employed by otologists. The Committee obtained the advice of Sir William Bragg 